\title{
ORGANIZATIONAL CITIZENSHIP BEHAVIORS IN PUBLIC AND PRIVATE SECTOR*
}

\author{
Aldona Glińska-Neweś", Dawid Szostek***
}

\begin{abstract}
Organizational citizenship behaviors (OCBs) are voluntary behaviors of organization members, going beyond their job descriptions, which aim at assisting coworkers and/or taking care of an organization and its operations. Since 1980's' many researchers contributed to the explanation of their nature, dimensions as well as antecedents, however, less attention has been paid to differences in OCB scale and frequency caused by an organization type. In the paper we verify the hypothesis that employees of for-profit private organizations engage in OCBs more frequently than employees of the public sector. The hypothesis is verified on a basis of a quantitative study conducted among 280 employees of the private sector and 244 employees of local government units. The analysis of the data brings contradictory results. In general, employees of the public sector organizations perform OCB more frequently than employees of the private sector. However, their OCBs are people-oriented. OCBs supporting an organization are more frequent among employees of the private sector.
\end{abstract}

Keywords: organizational citizenship behaviors, OCB, public and private sector. JEL Classification: D23

\section{INTRODUCTION}

Development of organizational behaviors' discipline within management studies leads to elaboration of specific constructs explaining and describing employee behaviors in an organization. Organizational citizenship behaviors (OCBs) represent extra-role employee behaviors that going beyond the call of duty support an organization and its members.

\footnotetext{
* The project was funded by the National Science Centre, Poland, on the decision number DEC-2017/25/B/HS4/01113.

*** Nicolaus Copernicus University in Toruń. E-mail: aldona.glinska@umk.pl

*** Nicolaus Copernicus University in Toruń. E-mail: dawidsz@umk.pl
} 
They may be directed towards other employees, e.g. through helping them spontaneously, or towards an organization, for instance through suggesting some improvements or protecting the organization's image outside. The importance of those behaviors was recognized back in the 1960s, when Katz (1964) underlined that organizational performance is dependent on everyday spontaneous acts of collaboration, mutual help, altruism and other employee behaviors of that kind. In his opinion, organizations that rely only on formal assignments of organizational roles are not stable social systems.

OCBs are well recognized in management studies, including propositions of their measurement and identification of their antecedents. Surprisingly, less attention has been paid so far to an impact that an organization type, namely private or public, may have on OCB scope and frequency among employees. The issue is particularly relevant as behaviors standing for opposite to OCB, i.e. so-called counter-productive work behaviors (CWB) are proved to appear more frequently in public sector organizations. We hypothesize then that, by analogy, OCBs are more frequent among employees of the private sector.

In order to verify the hypothesis we conducted a study among 524 employees representing both the public and the private sector. The analyses of the data reveal a complex picture of OCBs in those two sectors. While public sector employees in general perform OCB more frequently than employees of the private sector, their acts are primarily oriented toward coworkers. OCBs organization-oriented are more frequent among employees of the private sector.

The article contains four main parts: theoretical background, research methodology, results, discussion and conclusions.

\section{THEORETICAL BACKGROUND}

\section{Organizational Citizenship Behaviors}

Contemporary organizations of various kinds are more often than ever built on team-work. Consequently, their success is dependent on individual initiative and willingness to contribute to the collective results (LePine et al., 2002). Among various constructs identified in management studies, organizational citizenship behaviors (OCBs) represent and explain particularly beneficial individual employee 
behaviors supporting overall organizational performance (Glińska-Neweś \& Lis, 2016).

One of the first definitions of OCBs was created by Organ (1988), who said that OCB is "an individual behavior that is discretionary, not directly or explicitly recognized by the formal reward system, and that in the aggregate promotes the effective functioning of the organization" (Organ, 1988, p. 4). In other words, OCBs represent extra-role behaviors and as such belong to the same group as prosocial behaviors (Brief \& Motowidlo, 1986), organizational spontaneity (George \& Brief, 1992) or contextual performance (Borman \& Motowidlo, 1993). In order to distinguish organizational citizenship behaviors from those concepts, Organ proposed another definition stating that OCBs are "contributions to the maintenance and enhancement of the social and psychological context that support task performance" (1997, p. 91). The definition helps also to avoid ambiguity created by terms such as "discretion" or "direct/explicit recognition". To sum up, OCBs are behaviors that: are not included in an employee contract or job description, and are beneficial for organizational efficiency (Smith et al., 1983; Appelbaum et al., 2004; Cichorzewska \& Rakowska, 2017). Employees conduct them without expectations of rewards, motivated by intrinsic willingness to support the organization and its development (Organ et al., 2006; Nezakati et al., 2010).

There are different proposals regarding OCB elements and dimensions. Most works on the topic are based on Podsakoff et al. (2000) who identified the following:

1) altruism, which is expressed through voluntary helping workmates in problematic moments in the workplace, such as too heavy workload after long absence;

2) courtesy, i.e. preventing workmates from the occurrence of problematic situations, accompanied by an awareness of own behaviors' impact on others' work;

3) organizational compliance, which means internalization, acceptance and strict adherence to organizational procedures and policies; in practice it means that an individual obeys organizational norms even though nobody can see it;

4) sportsmanship, i.e. readiness to tolerate any inconvenient conditions in the workplace and to cope with them without complaints;

5) organizational loyalty that includes promoting an organization outside, protecting it against external threats and showing commitment to it in hardship; 
6) individual initiative, expressed through performing activities surpassing standard requirements, such as proposing improvements for an organization or voluntarily engaging in additional responsibilities;

7) civic virtue, which means willingness to participate in governance process and to take responsibility for the whole organization, including attending organization meetings or voluntarily monitoring the organizational environment to identify potential threats and opportunities;

8) self-development, i.e. voluntary engagement in any form of learning and training in order to gain new knowledge and improve skills and competencies.

While the aforementioned categorization of OCBs is very popular among organization scholars and it is helpful in explaining the construct nature, the framework as the whole is less useful in research. It is due to a fact that while some dimensions, e.g. altruism and courtesy, are well described and their measures have been validated by many researchers, the others are less studied and still under process of operationalization (Organ, 1997; Podsakoff et al., 2000). For this reason in our study we use another framework, proposed by Spector and Fox (2010). These authors are better known and associated with a construct reverse to OCB, i.e. counter-productive work behaviors (CWBs) (Spector \& Fox, 2010). CWBs stand for behaviors manifested in order to to harm an organization or its members. In fact, Spector and Fox's interest in CWBs makes an advantage of their approach to OCB. Their Organizational Citizenship Behavior Checklist (OCB-C) (Fox et al., 2012) has been designed to minimize overlap with CWB scale, which was a limitation noted in prior studies (Dalal, 2005; Spector et al., 2010). The proposition includes items related to Podsakoff' at al.'s model, however they are categorized in 2 main dimensions, i.e. behaviors directed toward the organization (OCB-O) and behaviors toward people in the organization (OCB-P). Table 1 presents items that we used in our study. 
Table 1. OCB measures used in the study

\begin{tabular}{|c|l|}
\hline $\begin{array}{c}\text { Item } \\
\text { Number }\end{array}$ & \multicolumn{1}{c|}{ Item } \\
\hline & OCB-O \\
\hline 1 & Helped new employees get oriented to the job. \\
\hline 2 & Offered suggestions to improve how work is done. \\
\hline 3 & Offered suggestions for improving the work environment. \\
\hline 4 & Volunteered for extra work assignments. \\
\hline 5 & Said good things about your employer in front of others. \\
\hline 6 & Gave up meal and other breaks to complete work. \\
\hline 7 & OCB-P \\
\hline 8 & Lent a compassionate ear when someone had a work problem. \\
\hline 9 & $\begin{array}{l}\text { Lent a compassionate ear when someone had a personal problem. } \\
\text { needs. }\end{array}$ \\
\hline 10 & Helped a less capable co-worker lift a heavy box or other object. \\
\hline 11 & Went out of the way to give co-worker encouragement or express appreciation. \\
\hline 12 & $\begin{array}{l}\text { Defended a co-worker who was being "put-down" or spoken ill of by other } \\
\text { co-workers or supervisor. }\end{array}$ \\
\hline
\end{tabular}

Source: Organizational Citizenship Behavior Checklist. Retrieved from: http://shell.cas.usf. edu/ pspector/scales/ocbcpage.html (access: 26.01.2018).

\section{OCB antecedents}

Most of the researchers underline 4 main categories of OCB antecedents (Podsakoff et al., 2000; Peyrat-Guillard \& Glińska-Neweś, 2010). They include individual (employee) characteristics, task characteristics, organizational characteristics and leadership behaviors. The comprehensive studies reveal that the strongest antecedents of OCBs are: job attitudes, task variables and leadership behaviors. In the first category, particularly job satisfaction, perception of fairness and organizational commitment strongly influence employee willingness to engage in OCBs. Tasks supporting OCB appearance should be intrinsically satisfying and accompanied with feedback. Among leadership characteristics, key antecedents include: supportive leader behaviors, transformational leadership and leader-follower exchange (Podsakoff et al., 1990).

Definitely less attention has been paid to the type of an organization as a factor of OCB. Notably, it is worth investigating whether belonging to the private vs. public sector determines a scope of OCB in 
an organization. While extra-role, organization-supporting employee behaviors are relevant in every kind of the organization, the public sector is a sector of public trust and its employees should especially demonstrate higher ethical standards (Ikola-Norrbacka, 2010; Rakowska et al., 2014). The question of the sector influence on OCBs arises particularly because there is a strong evidence that CWBs, constituting the antonym to OCBs, appear more often in organizations of the public sector (Burned \& Pope, 2007; Zapf et al., 2003; Leymann, 1996; Chartered Society of Physiotherapy, 1997; Nasir \& Bashir, 2012). There are various possible explanations of this phenomenon, including less mobility of employees (Zapf et al., 2003), excessive bureaucracy, depersonalized organizational structures, centralized management and lower salaries that may lead to higher level of employee frustration (Leymann, 1996; Chartered Society of Physiotherapy, 1997, Nasir \& Bashir, 2012).

If CWBs occur more often in the public sector organizations, will OCBs be more present in the private sector? In our study we put forward such a hypothesis that the level of OCBs in the private sector organizations is higher than in the public sector.

\section{RESEARCH METHODOLOGY}

To test the hypothesis we adopted a quantitative approach using a structured questionnaire. It consisted of items adopted from Spector and Fox's OCB Checklist (...) indicated in Table 1. We measured these items with five point Likert frequency scale. This scale is preferred over acceptance scale in such type of research as the acceptance scale may lead a respondent to biases caused by moral judgments. We conducted the study in 2017. In order to gain equivalent samples from both the private and the public sector, we used the convenience sampling, i.e. we sent the questionnaires to students of our Faculty who work, to employees of companies that we cooperate with and to local government units. The research study sample consisted of 524 respondents. Table 2 contains the structure of the research sample. 
Table 2. Research sample

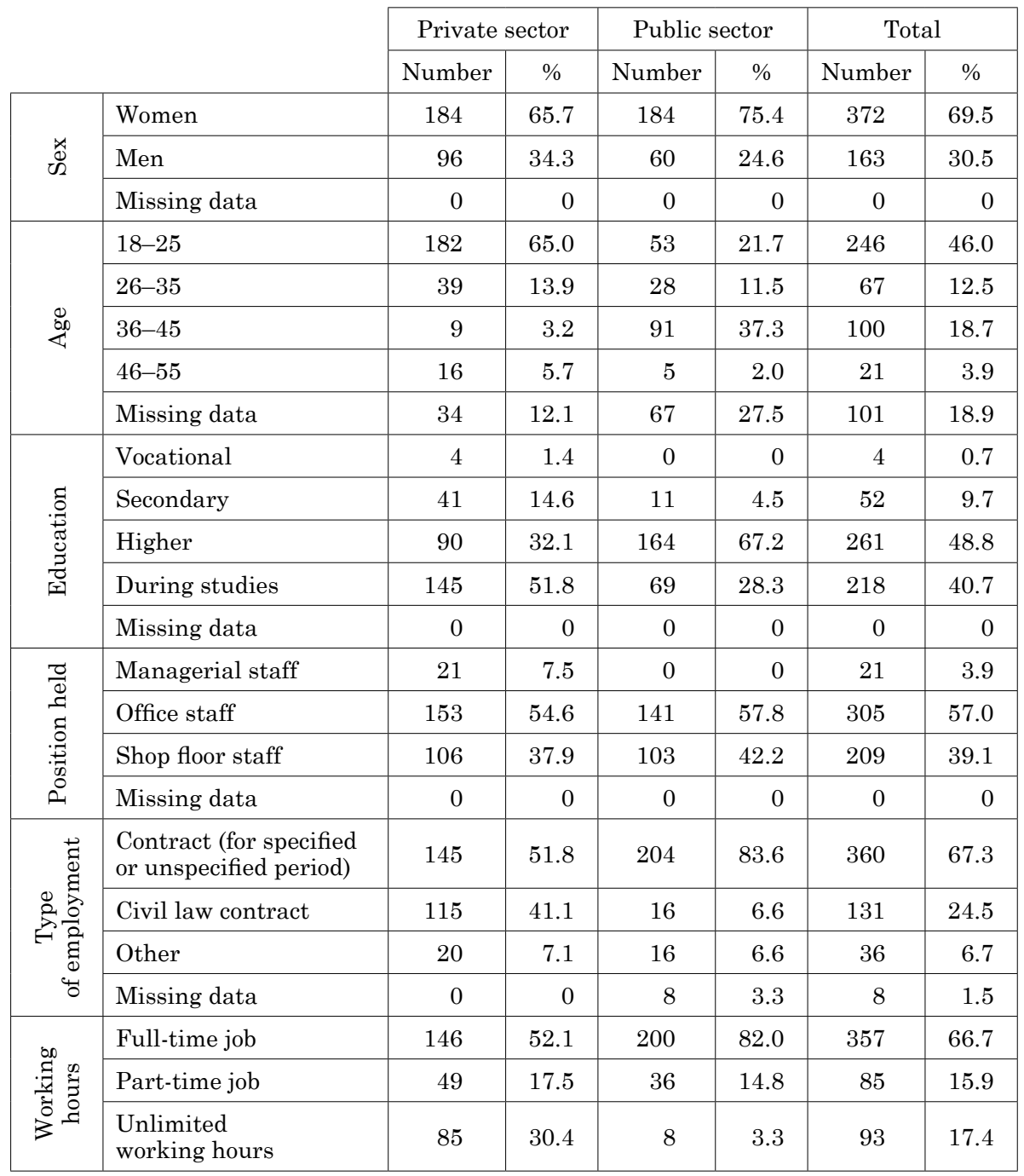

$\mathrm{N}=535$ (private sector $=280 / 52,3 \%$, public sector $=244 / 45,6 \%$, missing data $=11 / 2,1 \%$ )

Source: own research.

\section{RESULTS}

Table 3 presents descriptive statistics (M, SD) and Cronbach alpha coefficients for the whole construct of OCB as well as for OCB-O and OCB-P with regard to the respondents sector, i.e. private or public. 
Table 3. Descriptive statistics

\begin{tabular}{|l|c|c|c|}
\cline { 2 - 4 } \multicolumn{1}{c|}{} & M & SD & Cronbach alpha \\
\hline OCB & 2.619 & 0.510 & 0.918 \\
\hline Private sector & 2.576 & 0.546 & 0.919 \\
\hline Public sector & $\mathbf{2 . 5 8 9}$ & 0.499 & 0.885 \\
\hline OCB-O & 2.716 & 0.428 & 0.753 \\
\hline Private sector & $\mathbf{2 . 7 3 9}$ & 0.447 & 0.746 \\
\hline Public sector & 2.615 & 0.415 & 0.703 \\
\hline OCB-P & 2.421 & 0.635 & 0.817 \\
\hline Private sector & 2.371 & 0.673 & 0.792 \\
\hline Public sector & $\mathbf{2 . 3 9 8}$ & 0.617 & 0.808 \\
\hline
\end{tabular}

Source: own research.

The differences in the answer structure of the two samples, i.e. the private and the public sector employees, are depictured in Figure 1 and Figure 2.

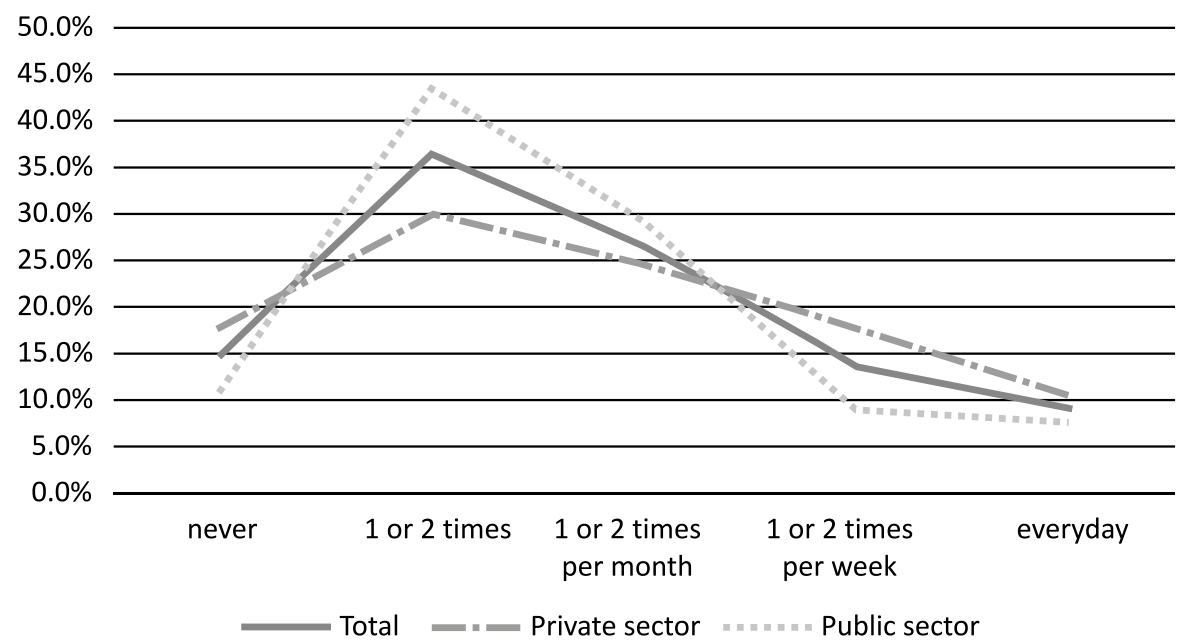

Figure 1. Frequency of OCB-O

Source: own research.

Table 3 as well as Figures 1 and 2 show interesting and complex picture of OCB in 2 studied sectors. In general, employees of the public sector perform OCBs more often than employees of the private sector. However, when it comes to detailed OCB dimensions, employees of the 
public sector appear to perform primarily behaviors towards coworkers. OCBs that are organization-oriented are more often among employees of the private sector. Moreover, it happens more often in the public sector that employees perform OCB occasionally, while in the private sector employees do this in a more regular manner. At the same time more employees of the private sector admitted that they did not perform OCB at all. In both groups everyday acts of OCBs are rare.

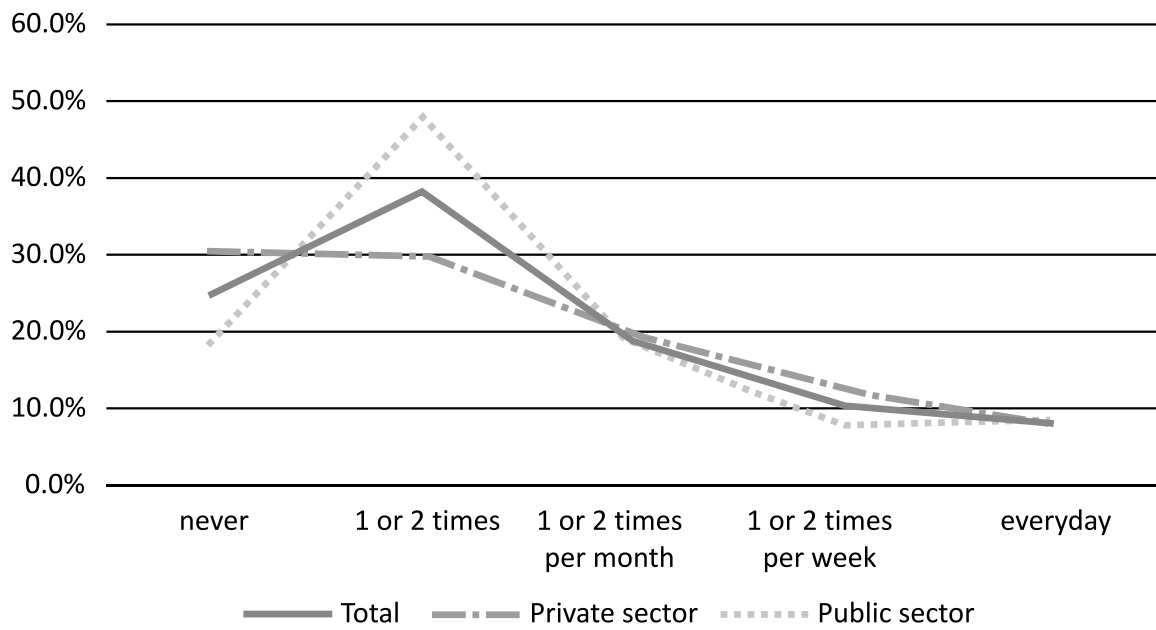

Figure 2. Frequency of OCB-P

Source: own research.

In order to determine if the relation between OCB frequency and a respondent's sector is significant we used chi-square coefficient. Table 4 presents the results of this analysis. All the relations are statistically significant.

Table 4. Pearson chi-square coefficients for OCBs in private and public sector

\begin{tabular}{|l|c|c|c|}
\cline { 2 - 4 } \multicolumn{1}{c|}{} & \multicolumn{3}{c|}{ Public or private sector and OCBs } \\
\hline Chi-square & OCB-O & OCB-P & OCB \\
\hline df & 60.136 & 120.301 & 56.188 \\
\hline P & 5 & 5 & 5 \\
\hline
\end{tabular}

$* p<0.01$

Source: own research. 


\section{DISCUSSION AND CONCLUSIONS}

The analyses of the data collected in our survey do not support the hypothesis stating that the level of OCBs in the private sector organizations is higher than in the public sector. However, the picture of OCBs in those two sectors is more complex and ambiguous. The private sector employees perform behaviors supporting organization itself more frequently, notably the OCB-Os. It is rarer in the public sector, which stays in line with aforementioned evidence that in the public sector employees are more likely to feel frustration and disappointment leading to acts harming their organization (CWBs). As Nasir and Bashir state, in the public sector "lower level of job satisfaction leads to deviating behaviors such as wasting organizational resources, delaying tasks, wasting time, stealing, etc." (Nasir \& Bashir, 2012, p. 247). Accordingly, this situation may lead to fewer acts of manifestation of their care towards an organization (OCB-O) than among employees of the private sector, which has been proved by our study.

The private sector employees seem to be more committed to their organizations and are more willing to do something extra for them. At the same time though, the public sector employees go beyond their call of duty to help coworkers, i.e. they perform OCB-P more often than the private sector employees. This may support a view that less favorable work conditions in the public sector reinforce employee cohesion and their readiness to help each other. In our study, such attitude is less common among the private sector employees, who in comparison with their counterparts in the public sector, appear to be more loyal to their organizations than to coworkers.

Our study has some limitations. First of all, we have not used the random sampling. As the result, the research sample was dominated by people with higher education. Research on a more numerous and diversified sample is required to confirm the findings. Moreover, the quantitative research method unabled us to grasp a broader context of OCB in studied sectors, notably other factors determining frequency of OCBs performed by employees of the two sectors. Nevertheless, we proved that the sector matters and further studies, particularly of qualitative nature, are recommended to investigate the specific relations in the area. 
With regard to the practical implications of our study, it shows interesting patterns in employee behaviors of the public and the private sector. Managers should be aware that employees' commitment has different objectives in these two sectors. In the private sector employees are more likely to do some extra activities for their organization, while in the public sector employees are more coworkers-oriented. Thus, managers' efforts made in order to enhance overall employee contribution to organizational performance should be different. Managers in the private sector should focus on building stronger social ties in an organization, while managers in the public sector should focus on strengthening employees' loyalty to an organization.

\section{REFERENCES}

Appelbaum, S., Bartolomucci, N., Beaumier, E., Boulanger, J., Corrigan, R., Dore, I., Girard, C. \& Serroni, C. (2004). Organizational citizenship behavior: A case study of culture, leadership and trust. Management Decision, 42(1), 13-40.

Borman, W.C. \& Motowidlo, S.J. (1993). Expanding the criterion domain to include elements of contextual performance. In: W.C. Schmitt, W.C. Borman (eds.), Personal Selection in Organizations (pp. 71-98). New York: Jossey-Bass.

Brief, A.P. \& Motowidlo S.J. (1986). Prosocial organizational behaviors. Academy of Management Review, 11(4), 710-725.

Burned, B. \& Pope, R. (2007). Negative behaviours in the workplace: A study of two Primary Care Trusts in the NHS. International Journal of Public Sector Management, 4(20), 285-303.

Chartered Society of Physiotherapy (1997). Bullying at Work, Employment Relations and Union Services Health and Safety Briefing Pack, 5(5). London: CSP.

Cichorzewska, M. \& Rakowska, A. (2017). Organizational citizenship behavior of Polish and Ukrainian civil servants - a comparative study. Management, Knowledge and Learning International Conference 2017. Technology, Innovation and Industrial Management. Retrieved from: http://www.toknowpress. net/ISBN/978-961-6914-21-5/papers/ML17-078.pdf (access: 15.01.2018).

Dalal, R.S. (2005). A meta-analysis of the relationship between organizational citizenship behavior and counterproductive work behavior. Journal of Applied Psychology, 90(6), 1241-1255.

George, J.M. \& Brief, A.P. (1992). Feeling good-doing good: A conceptual analysis of the mood at work-organizational spontaneity relationship. Psychological Bulletin, 112, 310-329. 
Glińska-Neweś, A. \& Lis, A. (2016). Paradoks współwystępowania organizacyjnych zachowań obywatelskich i kontrproduktywnych. Prace Naukowe Uniwersytetu Ekonomicznego we Wroctawiu, 422, 265-274.

Ikola-Norrbacka, A.S.R. (2010). Trust, good governance and unethical actions in Finnish public administration. International Journal of Public Sector Management, 23(7), 647-668.

Katz, D. (1964). The motivational basis of organizational behavior. Behavioral Science, 9(2), 131-146.

LePine, J.A., Erez, A. \& Johnson, D.E. (2002). The nature and dimensionality of organizational citizenship behavior: A critical review and meta-analysis. Journal of Applied Psychology, 87(1), 52-65.

Lewicka, D. (ed.) (2014). Zapobieganie patologiom w organizacji. Warszawa: Wydawnictwo Naukowe PWN.

Leymann, H. (1996). The content and development of mobbing at work. European Journal of Work and Organizational Psychology, 5, 165-184.

Nasir, M. \& Bashir, A. (2012). Examining workplace deviance in public sector organizations of Pakistan. International Journal of Social Economics, 39(4), 240-253.

Nezakati, H., Asgari, O., Karimi, F. \& Kohzadi, V. (2010). Fostering Organizational Citizenship Behavior (OCB) through Human Resource Empowerment (HRE). World Journal of Management, 2(3), 47-64.

Organ, D.W. (1988). Organizational Citizenship Behaviour: The Good Soldier Syndrome. Lexington: Lexington Books.

Organ, D.W. (1997). Organizational citizenship behavior: It's construct clean-up time. Human Performance, 10(2), 85-97.

Organ, D.W., Podsakoff, P.M. \& McKenzie, S.B. (2006). Organizational Citizenship Behavior: Its Nature, Antecedents, and Consequences. Thousand Oaks: Sage.

Organizational Citizenship Behavior Checklist. Retrieved from: http://shell.cas.usf. edu/ pspector/scales/ocbcpage.html (access: 26.01.2018).

Peyrat-Guillard, D. \& Glińska-Neweś, A. (2010). Positive organizational potential, organizational commitment and organizational citizenship behavior: A French/ Polish comparison. Journal of Positive Management, 1(1), 47-64.

Podsakoff, P.M., MacKenzie, S.B., Moorman, R.H. \& Fetter, R. (1990). Transformational leader behaviors and their effects on followers' trust in leader, satisfaction, and organizational citizenship behaviors. Leadership Quarterly, 1(2), 107-142.

Podsakoff, P.M., MacKenzie, S.B., Paine, J.B. \& Bachrach, D.G. (2000). Organizational citizenship behaviors: A critical review of the theoretical and empirical literature and suggestions for future research. Journal of Management, 26(3), 513-563. 
Rakowska, A., Valdes-Conca, J. \& de Juana-Espinosa, S. (2014). Affecting factors of public employees' organizational commitment. International Journal of Research and Synergy, 3, 5-24.

Smith, C.A., Organ, D.W. \& Near, J.P. (1983). Organizational citizenship behavior: Its nature and antecedents. Journal of Applied Psychology, 68(4), 653-663.

Spector, P.E. \& Fox, S. (2010). Counterproductive work behavior and organizational citizenship behavior: Are they opposite forms of active behavior? Applied Psychology: An International Review, 59(1), 21-39.

Spector, P.E., Bauer, J.A. \& Fox, S. (2010). Measurement artifacts in the assessment of counterproductive work behavior and organizational citizenship behavior: Do we know what we think we know? Journal of Applied Psychology, 95(4), 781-790.

Fox, S., Spector, P.E., Goh, A., Bruursema, K. \& Kessler, S.R. (2012). The deviant citizen: Measuring potential positive relations between counterproductive work behaviour and organizational citizenship behavior. Journal of Occupational and Organizational Psychology, 85, 199-220.

Zapf, D., Einarsen, S., Hoel, H. \& Vartia, M. (2003). Empirical findings on bullying. In: S. Einarsen, H. Hoel, D. Zapf, C.L. Cooper (eds.), Bullying and Emotional Abuse in the Workplace: International Perspectives in Research and Practice. London: Taylor \& Francis. 


\section{ZACHOWANIA OBYWATELSKIE W SEKTORZE PUBLICZNYM I PRYWATNYM}

Zachowania obywatelskie (OCB) to dobrowolne zachowania członków organizacji wykraczające poza obowiązki przypisane do danego stanowiska pracy, których celem jest wsparcie współpracowników i/lub samej organizacji oraz jej działań. Od lat 80 . XX wieku wielu badaczy starało się wyjaśnić ich naturę, a także zidentyfikować ich wymiary i uwarunkowania, jednak mniej uwagi poświęcano różnicom w OCB spowodowanym przez typ organizacji. W artykule weryfikujemy hipotezę, że pracownicy sektora prywatnego częściej angażuja się w OCB niż pracownicy sektora publicznego. Hipotezę zweryfikowano na podstawie badania ilościowego przeprowadzonego wśród 280 pracowników sektora prywatnego i 244 pracowników jednostek samorząu terytorialnego. Analiza danych prowadzi do sprzecznych wniosków. Ogólnie rzecz biorąc, pracownicy sektora publicznego częściej angażuja się w OCB niż pracownicy sektora prywatnego, jednak ich zachowania sa zorientowane na ludzi. Zachowania obywatelskie wspierające organizację są częstsze wśród pracowników sektora prywatnego.

Słowa kluczowe: zachowania obywatelskie, OCB, sektor prywatny i publiczny. 